\title{
Clostridium aciditolerans sp. nov., an acid-tolerant spore-forming anaerobic bacterium from constructed wetland sediment
}

Correspondence Juergen Wiegel jwiegel@uga.edu
Micro-organisms are the most dominant form of life in acidic environments. However under this condition, many micro-organisms are killed, distorted or become cytoplasm deficient (Wortman et al., 1986). A few anaerobic microorganisms have been isolated and characterized from low $\mathrm{pH}$ environments, including methanogens (Williams \& Crawford, 1985; Horn et al., 2003) and clostridia (Hamman \& Ottow, 1976; Kuhner et al., 2000). Since members of the genus Clostridium are metabolically versatile and capable of forming endospores, they are ubiquitous and can be found in various extreme environments such as the deep-sea, hot springs and the intestinal tracts of animals.

In this paper, we report the characterization of an anaerobic, acid-tolerant, spore-forming bacterium which falls into the radius of the genus Clostridium sensu stricto (Wiegel et al., 2005), formerly known as Collins' cluster I and II of the genus Clostridium (Collins et al., 1994).

A constructed wetland system was built to treat acid sulfate water at the US Department of Energy's Savannah River Site

The GenBank/EMBL/DDBJ accession number for the 16S rRNA gene sequence of strain JW/YJL-B3 ${ }^{\top}$ is DQ114945. near Aiken, SC, USA. The acid sulfate water $(\mathrm{pH} \sim 2.0)$ was introduced at the top of each cylindrical cell in the system, containing sand mixed with horse manure, wood chips and limestone. Within a few months of operation, the sediment developed a series of different reaction zones that were distinguishable based on a variety of physico-chemical attributes (Thomas, 2003; Lee, 2005). Sediment samples for the enrichments were taken from the top layer of the core where conditions were relatively oxidized, the $\mathrm{pH}$ was around 3.5 and the sediment was dominated by iron oxyhydroxide.

Enrichments under anaerobic and acidic conditions ( $\mathrm{pH} 3.5,4.5$ and 5.5) were prepared using a medium designed for sulfate-reducing bacteria (Widdel \& Bak, 1992) using a modified Hungate technique (Ljungdahl \& Wiegel, 1986). The medium contained either acetate $(15 \mathrm{mM})$ or lactate $(15 \mathrm{mM})$ as the sole carbon source and energy source supplemented with $0.1 \%$ yeast extract. The enrichments were incubated at $37^{\circ} \mathrm{C}$ for up to one month.

A pure isolate, designated strain JW/YJL-B3 ${ }^{\mathrm{T}}$, was obtained from the enrichments by three subsequent rounds of single colony isolation using the agar $(1.5 \% \mathrm{w} / \mathrm{v})$-shake-roll-tube 
technique (Ljungdahl \& Wiegel, 1986). Colonies of the isolate appeared after 1-2 days and were irregular, mostly translucent, filamentous and less than $1.5 \mathrm{~mm}$ in diameter.

For the phylogenetic analysis, DNA was extracted from the isolate as described previously (Lee et al., 2005) and amplified with a bacterial domain-specific primer set for the 16S rRNA gene, 27 forward and 1492 reverse (Lane, 1991). The PCR amplification was carried out with initial denaturation at $94^{\circ} \mathrm{C}$ for $2 \mathrm{~min}$ and followed by 10 cycles of denaturation $\left(94^{\circ} \mathrm{C}, 30 \mathrm{~s}\right)$, annealing $\left(58^{\circ} \mathrm{C}, 30 \mathrm{~s}\right)$ and extension $\left(72^{\circ} \mathrm{C}, 1 \mathrm{~min}\right), 10$ cycles of denaturation $\left(94^{\circ} \mathrm{C}\right.$, $30 \mathrm{~s})$, annealing $\left(58^{\circ} \mathrm{C}, 45 \mathrm{~s}\right)$ and extension $\left(72^{\circ} \mathrm{C}, 1 \mathrm{~min}\right.$ $15 \mathrm{~s})$ and 10 cycles of denaturation $\left(94^{\circ} \mathrm{C}, 30 \mathrm{~s}\right)$, annealing $\left(58^{\circ} \mathrm{C}, 1 \mathrm{~min}\right)$ and extension $\left(72{ }^{\circ} \mathrm{C}, 1 \mathrm{~min} 30 \mathrm{~s}\right)$. Final extension was for $7 \mathrm{~min}$ at $72^{\circ} \mathrm{C}$. PCR products were purified using a QIAquick PCR purification kit (Qiagen) and sequenced by Macrogen Inc. (Seoul, Korea). Retrieved $16 \mathrm{~S}$ rRNA gene sequences were analysed using BLAST and aligned manually against sequences obtained from the GenBank database using CLUSTAL_X v1.81 (Thompson et al., 1997) and GeneDoc v2.6.02 (www.psc.edu/biomed/genedoc). Phylogenetic trees were constructed by the neighbourjoining method (Saitou \& Nei, 1987) and FITCH (Fitch \& Margoliash, 1967) using the Jukes and Cantor model (Jukes \& Cantor, 1969) with the PHYLIP v3.6a2.1 phylogenetic analysis package (Felsenstein, 2001).

A nearly complete $16 \mathrm{~S}$ rRNA gene sequence was obtained for strain JW/YJL-B3 ${ }^{\mathrm{T}}$, comprising of $1391 \mathrm{bp}$ [approximate positions 47-1467 according to the Escherichia coli (GenBank accession number X80725) numbering scheme]. Based on 16S rRNA gene sequence similarity, strain JW/YJL$\mathrm{B} 3^{\mathrm{T}}$ fell into the radius of Clostridium sensu stricto (Wiegel et al., 2005). The closest relative was Clostridium drakei ( $96.2 \%$ gene sequence similarity) (Fig. 1).
Based on the phylogenetic analysis, further culturing of the isolate was performed in phosphate-buffered basal media containing $\left(\mathrm{l}^{-1}\right): 0.69 \mathrm{~g} \mathrm{NaH} \mathrm{PO}_{4} \cdot \mathrm{H}_{2} \mathrm{O}, 2.13 \mathrm{~g} \mathrm{Na}_{2} \mathrm{HPO}_{4}$, $0.5 \mathrm{~g} \mathrm{NH}_{4} \mathrm{Cl}, 0.01 \mathrm{~g} \mathrm{MgSO}_{4} .7 \mathrm{H}_{2} \mathrm{O}, 0.01 \mathrm{~g} \mathrm{CaCl}_{2}, 2 \mathrm{~g}$ glucose, $0.5 \mathrm{~g}$ yeast extract, $1 \mathrm{mg}$ resazurin and $0.05 \mathrm{~g}$ cysteine.HCl. Growth of pure cultures was determined by measuring the optical density at $600 \mathrm{~nm}$ using a spectrophotometer (Spectronic 21; Bausch \& Lomb).

Morphology was studied using light microscopy (VANOX phase-contrast microscope; Olympus) and transmission electron microscopy (100CX; JEOL). Vegetative cells grown in phosphate-buffered medium were straight rods, occurring singly or in pairs. The cells were $0.5-1.0 \mu \mathrm{m}$ in diameter and $3.0-9.0 \mu \mathrm{m}$ in length. Endospores detected in the late exponential growth phase were subterminal and oval in shape without swelling of the cells. Cells of strain JW/YJL$\mathrm{B} 3{ }^{\mathrm{T}}$ had peritrichous flagella (Fig. 2b), but motility was not observed during light microscopy. Cells stained Gramnegative at all growth phases (Doetsch, 1981), while electron microscopy and phylogenetic position indicated a Gramtype positive cell-wall structure (Fig. 2c) as expected from the 16S rRNA gene sequence-based phylogeny. Thus, the novel strain is Gram-stain negative but is Gram-type positive (Wiegel, 1981).

The temperature range for growth of the isolate was measured at $\mathrm{pH} 5.0$ using a temperature gradient incubator (Scientific Industries). Strain JW/YJL-B3 ${ }^{\mathrm{T}}$ grew at between 20 and $45^{\circ} \mathrm{C}$, with an optimum around $35^{\circ} \mathrm{C}$. Growth was not detected below $18{ }^{\circ} \mathrm{C}$ or above $47^{\circ} \mathrm{C}$. The $\mathrm{pH}^{25^{\circ} \mathrm{C}}$ (Wiegel, 1998) range for growth was determined using media buffered with $10 \mathrm{mM}$ each of MES, HEPES and TAPS in combination with $2 \mathrm{mM}$ phosphate. The $\mathrm{pH}^{25^{\circ} \mathrm{C}}$ range for growth was $\mathrm{pH} 3.8-8.9$, with an optimum at $\mathrm{pH}$ 7.0-7.5. Although the optimum $\mathrm{pH}$ was in the neutral range, the

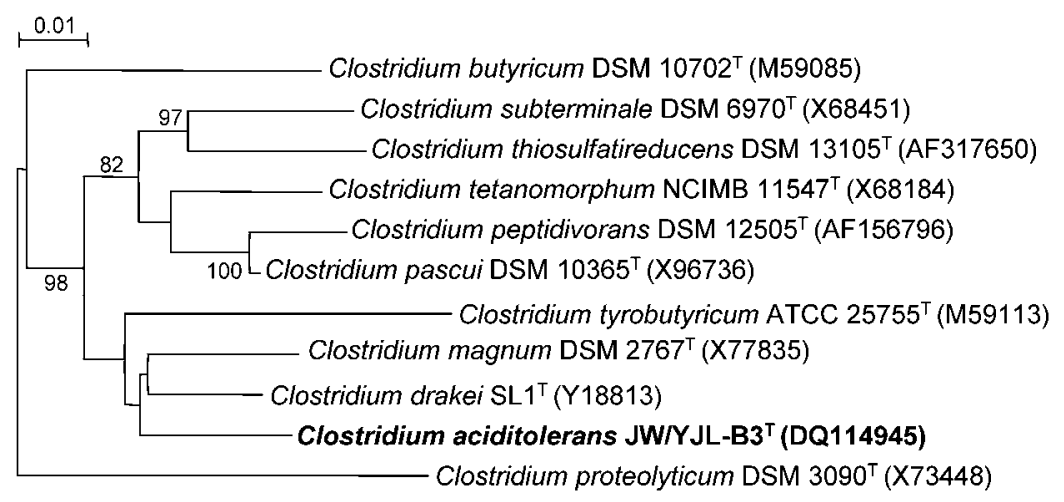

Fig. 1. A phylogenetic dendrogram based on $16 \mathrm{~S}$ rRNA gene sequences showing the position of strain JW/YJL-B3 ${ }^{\top}$ (bold type) among members of the genus Clostridium sensu stricto. The 16S rRNA gene sequence data used represents $E$. coli DSM $30083^{\top}$ nucleotide positions $47-1467$. The tree was constructed using the neighbour-joining method with Jukes and Cantor distance corrections. Numbers at the nodes represent the bootstrap values (1000 replicates); values above $80 \%$ are considered significant. Bar, 1 nucleotide substitution per 100 nucleotides. 


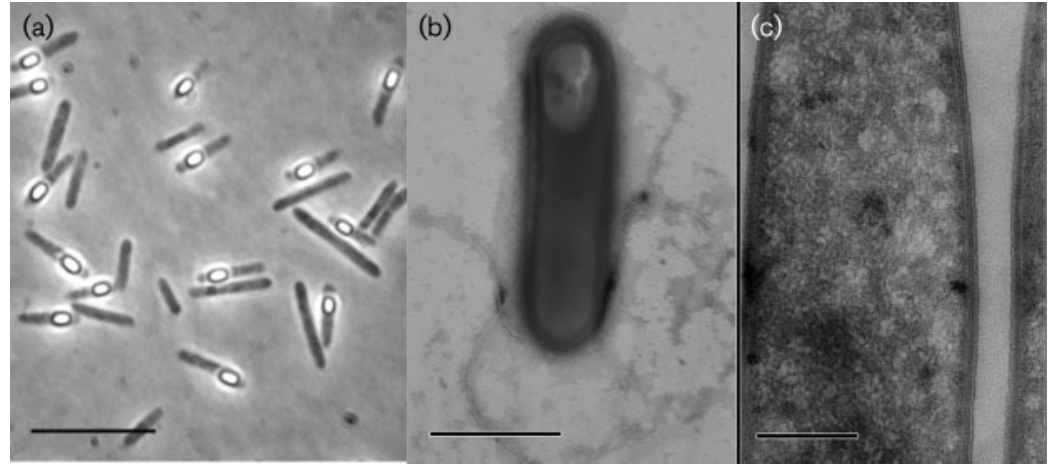

Fig. 2. Light micrograph (a) and electron micrographs of a negatively stained cell depicting retarded peritrichous flagellation (b) and an ultrathin section depicting the Gram-type type positive cell wall (c) of strain JW/YJL-B3 ${ }^{\top}$. Bars, $10 \mu \mathrm{m}$ (a), $1 \mu \mathrm{m}$ (b) and $0.5 \mu \mathrm{m}$ (c).

strain grew well under mildly acidic conditions, i.e., growth at $\mathrm{pH} 4.5-5.0$ occurred at $52 \%$ of the optimal growth rate. Growth was not detected at or below $\mathrm{pH} 3.5$ or at or above $\mathrm{pH}$ 9.2. The salinity range for growth was obtained using phosphate-buffered medium supplemented with various concentrations of $\mathrm{NaCl}$ and $\mathrm{KCl}(9: 1)$. The isolate grew optimally in the absence of $\mathrm{NaCl}$ and $\mathrm{KCl}$, but showed growth up to $1.5 \%(\mathrm{w} / \mathrm{v})$ salinity. No growth was detected at $2 \%$ salinity. The doubling time at $37^{\circ} \mathrm{C}$ and $\mathrm{pH}^{25^{\circ} \mathrm{C}} 6.5$ with $0.3 \%$ glucose was $1.7 \mathrm{~h}$. Detailed results of other morphological and physiological characteristics are summarized and compared with closely related species in Table 1.

Biochemical features of the novel isolate were tested using the API ZYM system (bioMérieux) and positive reactions were recorded for alkaline phosphatase, esterase, acid phosphatase and naphthol-AS-BI-phosphohydrolase. Strain JW/ YJL-B ${ }^{\mathrm{T}}$ exhibited positive reactions for the methyl red test, indole production and lecithinase, but was negative for the Voges-Proskauer reaction (Smibert \& Krieg, 1994) and lipase. Gelatin was hydrolysed, but not casein. Haemolysis

Table 1. Morphological and physiological characteristics of strain JW/YJL-B3 ${ }^{\top}$ and its closest relatives

Strains: 1, JW/YJL-B3 ${ }^{\mathrm{T}}$ (data from this study); 2, Clostridium drakei SL1 ${ }^{\mathrm{T}}$ (Küsel et al., 2000; Liou et al., 2005); 3, Clostridium scatologenes ATCC $25775^{\mathrm{T}}$ (Küsel et al., 2000; Liou et al., 2005); 4, Clostridium carboxidivorans $\mathrm{P}^{\mathrm{T}}$ (Liou et al., 2005). NR, Not reported.

\begin{tabular}{|c|c|c|c|c|}
\hline Characteristic & 1 & 2 & 3 & 4 \\
\hline Temperature range $\left({ }^{\circ} \mathrm{C}\right)$ & $20-45$ & $18-42$ & $18-42$ & $24-42$ \\
\hline Optimum temperature $\left({ }^{\circ} \mathrm{C}\right)$ & 35.5 & $30-37$ & $37-40$ & $37-40$ \\
\hline Salinity range $(\% \mathrm{NaCl})$ & $0-1.5$ & NR & NR & NR \\
\hline Optimum salinity $(\% \mathrm{NaCl})$ & 0 & NR & $\mathrm{NR}$ & NR \\
\hline DNA G $+\mathrm{C}$ content $(\mathrm{mol} \%)^{*}$ & 30.8 & 32 & 31 & 31 \\
\hline Gram stain & - & - & $\mathrm{NR}$ & + \\
\hline Spores observed & $+($ subterminal, oval $)$ & $+($ terminal $)$ & + & $\begin{array}{l}\text { Rare (subterminal } \\
\text { to terminal) }\end{array}$ \\
\hline \multicolumn{5}{|l|}{ Utilization of: } \\
\hline Inositol & - & + & + & + \\
\hline Lactose & + & - & - & - \\
\hline Maltose & + & - & + & - \\
\hline Mannitol & - & + & - & + \\
\hline Raffinose & + & - & - & - \\
\hline Sorbitol & - & - & + & - \\
\hline Trehalose & - & - & - & + \\
\hline
\end{tabular}

${ }^{\star}$ DNA G $+\mathrm{C}$ content was determined by nuclease digest. 
was detected on blood agar. The utilization of various carbon sources was studied using phosphate-buffered basal medium supplemented with $0.02 \%$ yeast extract and the test substrate. Strain JW/YJL-B3 ${ }^{\mathrm{T}}$ used beef extract, Casamino acids, peptone, tryptone, cellobiose, fructose, galactose, glucose, lactose, maltose, mannose, raffinose, ribose, sucrose, xylose, pyruvate, glutamate and inulin as carbon and energy sources. Acetate, lactate, arabinose, trehalose, inositol, mannitol, sorbitol, xylitol and cellulose did not support growth of the strain. There was no indication of autotrophic growth under an atmosphere of 15 p.s.i. of $\mathrm{CO}_{2}$ and $\mathrm{H}_{2}(80: 20)$. The strain grew in classical peptone-sugar media including peptone-yeast extract (PY), peptone-yeast extract-glucose (PYG), reinforced clostridial medium (RCM, Difco) and thioglycolate broth (Difco). The fermentation end products from glucose $(20 \mathrm{mM})$ were acetate, butyrate and ethanol. The potential use of electron acceptors was determined in cultures incubated for at least 2 weeks using phosphate-buffered basal medium containing $0.2 \%$ Casamino acids as an electron donor and an inoculum of $3 \%(\mathrm{v} / \mathrm{v})$ of an exponentially growing culture. The use of electron acceptors was determined by measuring growth $\left(\mathrm{OD}_{600}\right)$, sulfide, ammonium or nitrite production or colour-change. However, none of the following electron acceptors tested at $20 \mathrm{mM}$ was utilized: fumarate, nitrate, nitrite, sulfate, thiosulfate, elemental sulfur, Fe(III), 9,10anthraquinone 2,6-disulfonate (AQDS), $\mathrm{Mn}(\mathrm{IV})$ or sulfite at $2 \mathrm{mM}$. Oxygen was not used as a terminal electron acceptor when tested in a $150 \mathrm{ml}$ serum bottle laid horizontally containing $5 \mathrm{ml}$ culture (basal medium) and air as head gas.

Strain JW/YJL-B3 ${ }^{\mathrm{T}}$ was resistant only to tetracycline at $10 \mu \mathrm{M}$ and sensitive to $10 \mu \mathrm{M}$ ampicillin, chloramphenicol, erythromycin, rifampicin and streptomycin and $100 \mu \mathrm{M}$ tetracycline. The $\mathrm{G}+\mathrm{C}$ content of genomic DNA, determined by the HPLC method as described previously (Mesbah et al., 1989; Lee et al., 2005), was $30.8 \mathrm{~mol} \%$ (mean of 4 replicates of the nuclease digest and HPLC runs).

Based on morphological, physiological and phylogenetic characteristics, we propose to place strain JW/YJL-B3 ${ }^{\mathrm{T}}$ as the type strain of a novel taxon, Clostridium aciditolerans, sp. nov., belonging to the genus Clostridium sensu stricto within the family Clostridiaceae (Garrity et al., 2004; Wiegel et al., 2005).

\section{Description of Clostridium aciditolerans sp. nov.}

Clostridium aciditolerans (a.ci.di.to'le.rans. N.L. n. acidum an acid; L. part. adj. tolerans tolerating; N.L. part. adj. aciditolerans acid-tolerating).

Cells are straight to slightly curved rods, $0.5-1 \mu \mathrm{m}$ in diameter and 3.0-9.0 $\mu \mathrm{m}$ in length. Spores are subterminal and oval in shape and do not swell the cell. Retarded peritrichous flagellation is observed. Although the type strain stains Gram-negative at all growth phases, the strain is Gram-type positive. The temperature range for growth is $20-45^{\circ} \mathrm{C}$, with an optimum around $35^{\circ} \mathrm{C}$. No growth is observed at or below $18{ }^{\circ} \mathrm{C}$ or at or above $47^{\circ} \mathrm{C}$. The $\mathrm{pH}^{25^{\circ} \mathrm{C}}$ range for growth is from $\mathrm{pH} 3.8$ to 8.9 , with an optimum at $\mathrm{pH} 7.0-7.5$. Growth at $\mathrm{pH} 4.5-5.0$ takes place at $52 \%$ of the optimal growth rate; no growth is observed at or below $\mathrm{pH} 3.5$ or at or above $\mathrm{pH} 9.2$. The salinity range for growth is from 0 to $1.5 \% \mathrm{NaCl}(\mathrm{w} / \mathrm{v})$. In the presence of $0.02 \%$ yeast extract, the following substrates serve as carbon and energy source: beef extract, Casamino acids, peptone, tryptone, cellobiose, fructose, galactose, glucose, lactose, maltose, mannose, raffinose, ribose, sucrose, xylose, pyruvate, glutamate and inulin. $\mathrm{Fe}(\mathrm{III})$, nitrate, thiosulfate, elemental sulfur, sulfate, sulfite, $\mathrm{MnO}_{4}$ and fumarate are not used as electron acceptors. The main organic fermentation endproducts from glucose are acetate, butyrate and ethanol. The strain is resistant to tetracycline $(10 \mu \mathrm{M})$ and sensitive to ampicillin $(10 \mu \mathrm{M})$ chloramphenicol $(10 \mu \mathrm{M})$, erythromycin $(10 \mu \mathrm{M})$, rifampicin $(10 \mu \mathrm{M})$ and streptomycin $(10 \mu \mathrm{M})$. The $\mathrm{G}+\mathrm{C}$ content of the genomic DNA is $30.8 \mathrm{~mol} \%$ (HPLC).

The type strain, JW/YJL-B3 ${ }^{\mathrm{T}}\left(=\mathrm{DSM} \quad 17425^{\mathrm{T}}=\mathrm{ATCC}\right.$ BAA $-1220^{\mathrm{T}}$ ), was isolated from a sediment sample from a constructed wetland system receiving acid sulfate water.

\section{Acknowledgements}

This research was partially supported by Financial Assistance Award Number De-FC09-96SR18546 between the United States Department of Energy and the University of Georgia as a part of the US DOE National Water Research Center. We thank Robert C. Thomas for providing samples for this experiment, Jean P. Euzéby for his help with the nomenclature and Rich Davis for providing the electron micrographs.

\section{References}

Collins, M. D., Lawson, P. A., Willems, A., Cordoba, J. J., FernandezGarayzabal, J., Garcia, P., Cai, J., Hippe, H. \& Farrow, J. A. E. (1994). The phylogeny of the genus Clostridium: proposal of five new genera and eleven new species combinations. Int J Syst Bacteriol 44, 812-826.

Doetsch, R. N. (1981). Determinative methods of light microscopy. In Manual Methods for General Bacteriology, pp. 21-23. Edited by P. Gerhardt, R. G. E. Murray, R. N. Costilow, E. W. Nester, W. A. Wood, N. R. Krieg \& G. B. Philips. Washington, DC: American Society for Microbiology.

Felsenstein, J. (2001). PHYLIP - Phylogeny Inference Package, version 3.6a2.1. Department of Genome Sciences, University of Washington, Seattle, USA.

Fitch, W. M. \& Margoliash, E. (1967). Construction of phylogenetic trees: a method based on mutation distances as estimated by cytochrome c sequences is of general applicability. Science 155, 279-284.

Garrity, G. M., Bell, J. A. \& Lilburn, T. G. (2004). Taxonomic outline of the Prokaryotes. In Bergey's Manual of Systematic Bacteriology, 2nd edn, release 5.0. New York: Springer, http://dx.doi.org/10.1007/ bergeysoutline

Hamman, R. \& Ottow, I. G. G. (1976). Isolation and characterization of iron-reducing nitrogen-fixing saccharolytic clostridia from gley soils. Soil Biol Biochem 8, 357-364. 
Horn, M. A., Matthies, C., Küsel, K., Schramm, A. \& Drake, H. L. (2003). Hydrogenotrophic methanogenesis by moderately acidtolerant methanogens of a methane-emitting acidic peat. Appl Environ Microbiol 69, 74-83.

Jukes, T. H. \& Cantor, C. R. (1969). Evolution of protein molecules. In Mammalian Protein Metabolism, vol. 3, pp. 21-132. Edited by H. N. Munro. New York: Academic Press.

Kuhner, C. H., Matthies, C., Acker, G., Schmittroth, M., Gößner, A. \& Drake, H. L. (2000). Clostridium akagii sp. nov. and Clostridium acidisoli sp. nov.: acid-tolerant, $\mathrm{N}_{2}$-fixing clostridia isolated from acidic forest soil and litter. Int J Syst Evol Microbiol 50, 873-881.

Küsel, K., Dorsch, T., Acker, G., Stackebrandt, E. \& Drake, H. L. (2000). Clostridium scatologenes strain SL1 isolated as an acetogenic bacterium from acidic sediments. Int J Syst Evol Microbiol 50, 537-546.

Lane, D. J. (1991). 16S/23S rRNA sequencing. In Nucleic Acid Techniques in Bacterial Systematics, pp. 115-175. Edited by E. Stackebrandt \& M. Goodfellow. New York: Wiley.

Lee, Y.-J. (2005). Microbial diversity in a constructed wetland system for treatment of acid sulfate water. $\mathrm{PhD}$ thesis. University of Georgia, Athens, GA.

Lee, Y.-J., Wagner, I. D., Brice, M. E., Kevbrin, V. V., Mills, G. L., Romanek, C. S. \& Wiegel, J. (2005). Thermosediminibacter oceani gen. nov., sp. nov. and Thermosediminibacter litoriperuensis sp. nov., new anaerobic thermophilic bacteria isolated from Peru Margin. Extremophiles 9, 375-383.

Liou, J. S.-C., Balkwill, D. L., Drake, G. R. \& Tanner, R. S. (2005). Clostridium carboxidivorans sp. nov., a solvent-producing clostridium isolated from an agricultural settling lagoon, and reclassification of the acetogen Clostridium scatologenes strain SL1 as Clostridium drakei sp. nov. Int J Syst Evol Microbiol 55, 2085-2091.

Ljungdahl, L. G. \& Wiegel, J. (1986). Anaerobic fermentations. In Manual of Industrial Microbiology and Biotechnology, pp. 84-96. Edited by A. L. Demain \& N. A. Solomon. Washington, DC: American Society for Microbiology.
Mesbah, M., Premachandran, U. \& Whitman, W. B. (1989). Precise measurement of the $\mathrm{G}+\mathrm{C}$ content of deoxyribonucleic acid by highperformance liquid chromatography. Int J Syst Bacteriol 39, 159-167.

Saitou, N. \& Nei, M. (1987). The neighbor-joining method: a new method for reconstructing phylogenetic trees. Mol Biol Evol 4, 406-425.

Smibert, R. M. \& Krieg, N. R. (1994). Phenotypic characterization. In Methods for General and Molecular Bacteriology, pp. 607-654. Edited by P. Gerhardt, R. G. E. Murray, W. A. Wood \& N. R. Krieg. Washington, DC: American Society for Microbiology.

Thomas, R. C. (2003). Passive treatment of low $\mathrm{pH}$, ferric irondominated acid rock drainage. $\mathrm{PhD}$ thesis. University of Georgia, Athens, GA.

Thompson, J. D., Gibson, T. J., Plewniak, F., Jeanmougin, F. \& Higgins, D. G. (1997). The CLUSTAL_X windows interface: flexible strategies for multiple sequence alignment aided by quality analysis tools. Nucleic Acids Res 25, 4876-4882.

Widdel, F. \& Bak, F. (1992). Gram-negative mesophilic sulfatereducing bacteria. In The Prokaryotes, vol. 4, pp. 3352-3378. Edited by A. Balows, H. G. Trüper, M. Dworkin, W. Harder \& K. H. Schleifer. New York: Springer.

Wiegel, J. (1981). Distinction between the Gram reaction and the Gram type of bacteria. Int J Syst Bacteriol 31, 88.

Wiegel, J. (1998). Anaerobic alkalithermophiles, a novel group of extremophiles. Extremophiles 2, 257-267.

Wiegel, J., Tanner, R. \& Rainey, F. A. (2005). An introduction to the Family Clostridiaceae. In The Prokaryotes: a Handbook on the Biology of Bacteria. Vol. 4: Bacteria: Firmicutes, Cyanobacteria, 3rd edn. release 3.20. New York: Springer. http://141.150.157.117:8080/ prokPUB/metadata/releases/3.20.htm\#

Williams, R. T. \& Crawford, R. L. (1985). Methanogenic bacteria, including an acid-tolerant strain, from peatlands. Appl Environ Microbiol 50, 1542-1544.

Wortman, A. T., Voelz, H., Lantz, R. C. \& Bissonnette, G. K. (1986). Effect of acid mine water on Escherichia coli: structural damage. Curr Microbiol 14, 1-5. 